\title{
Overwintering of the Onion Thrips, Thrips tabaci (Thysanoptera: Thripidae), in New York
}

\author{
R. C. NORTH AND A. M. SHELTON \\ Department of Entomology, New York State Agricultural Experiment Station, \\ Cornell University, Geneva, New York 14456
}

\begin{abstract}
Environ. Entomol. 15: 695-699 (1986)
ABSTRACT A survey of overwintering thrips and the potential for Thrips tabaci Lindeman to overwinter in upstate New York were investigated during the winters of 1982-83 and 1983-84. Six species-T. tabact, Anaphothrips obscurtus (Müller), Chirothrips manicatus Haliday, Limothrips denticornis (Haliday), Frankliniella tenuicornis (Uzel), and Aptinothrips rufus (Gmelin)-were able to survive as adults in the vegetation sampled, but only Anaphothripini survived as larvae. T. tabaci adults overwinter within winter wheat, alfalfa, and weedy vegetation, and these overwintering females are capable of ovipositing on these plants during the spring. Winter wheat, oats, and alfalfa were the best oviposition and reproduction hosts we examined.
\end{abstract}

A PREvious STUDY BY Shelton \& North (1986) focused on determining the possible origins of thrips entering and infesting cabbage fields in upstate New York. Although that study examined the species composition and phenology of all Thysanoptera on the various field and forage crops examined, particular emphasis was placed on Thrips tabaci Lindeman, an important pest of cabbage and onions in the state. Before the appearance of thrips in cabbage and onion fields, significant numbers of adult females are present in various field and forage crops in early to midsummer. The origin of the founders of the thrips within the cereal and forage crops is unknown. They could be long-distance migrants that arrive in New York in the spring, as has been suggested for the movement of some thrips into northern latitudes (Stannard 1968), or they could overwinter here. Shirck (1951) reported collecting T. tabaci adults from alfalfa and red clover in Idaho from September to May, and Boyce \& Miller (1953) collected a mean of $<1$ adult per sample from alfalfa, red clover, winter wheat, oat, and grass sod during the coldest time periods (January-February) in southern Ontario, Canada.

The present study was initiated in 1982 to determine 1) the species composition of thrips that overwinter in several field crops and surrounding vegetation; 2 ) the ability of $T$. tabaci to overwinter in winter wheat and alfalfa and the ability of the survivors to reproduce on onions; and 3 ) the suitability of several hosts for T. tabaci oviposition and larval development.

\section{Materials and Methods}

Survey of Overwintering Thrips. Vegetative samples were examined for overwintering thrips from November through mid-April of 1982-83 and 1983-84. The samples consisted of four $320-\mathrm{cm}^{2}$ subsamples, with three samples per field per date. The four subsamples consisted of the top $2 \mathrm{~cm}$ of soil in which vegetation was growing. All four subsamples were collected within a 2 -m radius and placed together in labeled plastic bags. Thrips were extracted into a $70 \%$ ethanol and $1 \%$ formaldehyde solution in Berlese funnels (60-W bulb) for 3 days, and subsequently enumerated and identified. The larvae were identified to the tribe level utilizing the classification of Vance (1974). In 198283 , samples were taken at 2 -week intervals in three winter wheat, three alfalfa, two volunteer oat, and three cabbage fields, and six ditch areas adjacent to harvested cabbage fields. During 1983-84, two barley, three winter wheat, and three alfalfa fields, and six ditch areas were sampled (cabbage and oats were discontinued because no thrips were found throughout the previous year's sampling).

T. tabaci Overwintering on Wheat and Alfalfa. T. tabaci adults (1982-83) and adults and larvae (1983-84) were placed on winter wheat and alfalfa plants contained in plastic pots covered with screening (Nytex $85 \mu \mathrm{m}$, Tetko, Elmsford, N.Y.). This procedure was conducted in three winter wheat and three alfalfa fields in both winters. A cylinder was used to remove a plug $(10 \mathrm{~cm}$ diam, $10 \mathrm{~cm}$ deep) of winter wheat or alfalfa and their surrounding soil from commercial fields. Twelve plugs were collected from each of three rows in the alfalfa and winter wheat fields in October 1982-83 and 1983-84. The soil and foliage was placed in a plastic pot (10 cm diam). The bottom of the plug was trimmed so that the wheat shoots and alfalfa stems were not crushed or matted down when Nytex screen was placed over the pot. Within $48 \mathrm{~h}$ of collection of plugs, $T$. tabaci adults were individually removed from heads of cabbage and placed onto the wheat and alfalfa. After 25 adults (1982-83) were placed onto the foliage in each pot, they were covered with Nytex screen. The 
Table 1. Species of thrips collected from different vegetation during the winters of 1982-84; larvee are identified to tribe only

\begin{tabular}{|c|c|c|c|c|c|}
\hline \multicolumn{3}{|c|}{$1982-84$} & \multicolumn{2}{|c|}{$1982-83$} & \multirow{2}{*}{$\frac{1983-84}{\text { Barley }}$} \\
\hline Wheat & Alfalfa & Weedy vegetation & Oats & Cabbage & \\
\hline \multicolumn{6}{|l|}{ Nov. } \\
\hline $\begin{array}{l}\text { T. tabact } \\
\text { A. abscurus } \\
\text { C. manicatusa } \\
\text { F. triticia } \\
\text { F. tenuicornts } \\
\text { Thripini } \\
\text { Anaphothripini }\end{array}$ & $\begin{array}{l}\text { T. tabact } \\
\text { A. obscurus } \\
\text { F. triticia } \\
\text { F. tenuicomis }{ }^{a} \\
\text { Thripinja } \\
\text { Anaphothripini }\end{array}$ & $\begin{array}{l}\text { T. tabaci } \\
\text { A. obscurtus } \\
\text { C. manicatus } \\
\text { F. tenuicornis } \\
\text { A. rufus } \\
\text { Thripini }{ }^{b} \\
\text { Anaphothripini }\end{array}$ & $\begin{array}{l}\text { T. taboct } \\
\text { A. obscuress } \\
\text { Anaphothripini }\end{array}$ & $\begin{array}{l}\text { T. tabact } \\
\text { A. obscurus } \\
\text { Thripini }\end{array}$ & $\begin{array}{l}\text { T. tabact } \\
\text { L. denticornis } \\
\text { Thripini }\end{array}$ \\
\hline \multicolumn{6}{|l|}{ Dec. } \\
\hline $\begin{array}{l}\text { T. tabact } \\
\text { A. obscurus } \\
\text { F. tenuicornis } \\
\text { Thripini } \\
\text { Anaphothripini }\end{array}$ & $\begin{array}{l}\text { T. tabaci } \\
\text { A. obscurus } \\
\text { F. tenuicornis } \\
\text { Anaphothripini }\end{array}$ & $\begin{array}{l}\text { T. tabaci } \\
\text { A. obscurus } \\
\text { F. tenuicornis } \\
\text { A. rufus } \\
\text { Anaphothripini }\end{array}$ & $\begin{array}{l}\text { T. tabact } \\
\text { A. obscurus }\end{array}$ & $\begin{array}{l}\text { T. tabaci } \\
\text { Thripini }\end{array}$ & $\begin{array}{l}T \text { tabact } \\
L \text { denticornis } \\
\text { Tiaripini }\end{array}$ \\
\hline \multicolumn{6}{|l|}{ Jan. } \\
\hline $\begin{array}{l}\text { T. tabaci } \\
\text { A. obscurus } \\
\text { Thripini } \\
\text { Anaphothripini }\end{array}$ & $\begin{array}{l}\text { T. tabact } \\
\text { A. obscurus } \\
\text { F. tenutcornis } \\
\text { Anaphothripini }\end{array}$ & $\begin{array}{l}\text { T. tabaci } \\
\text { A. obscurus } \\
\text { A. rufus } \\
\text { Anaphothripini }\end{array}$ & $\begin{array}{l}\text { T. taboct } \\
\text { A. obscurus } \\
\text { F. tenuicornis }\end{array}$ & $\begin{array}{l}T \text {. tabact } \\
\text { Thripini }\end{array}$ & $\begin{array}{l}\text { A. obscurus } \\
\text { L. denticornis }\end{array}$ \\
\hline \multicolumn{6}{|l|}{ Feb. } \\
\hline $\begin{array}{l}\text { T. tabact } \\
\text { A. obscurus } \\
\text { F. tenuicornis } \\
\text { Anaphothripini }\end{array}$ & $\begin{array}{l}\text { T. tabact } \\
\text { A. obscurtus } \\
\text { Anaphothripini }{ }^{a}\end{array}$ & $\begin{array}{l}\text { T. tabaci } \\
\text { A. obscurus } \\
\text { A. rufus } \\
\text { Anaphothripini }\end{array}$ & & T. tabact & L. denticornis \\
\hline \multicolumn{6}{|l|}{ Mar. } \\
\hline $\begin{array}{l}\text { T. tabaci } \\
\text { A. obscurus } \\
\text { F. tenuicornis }\end{array}$ & Anaphothripinia & $\begin{array}{l}\text { T. tabaci } \\
\text { A. obscurus } \\
\text { C. manicatusa } \\
\text { F. tenuicornis } \\
\text { A. rufus } \\
\text { Anaphothripini }\end{array}$ & & & $\begin{array}{l}\text { T. tabact } \\
\text { L. denticornis }\end{array}$ \\
\hline \multicolumn{6}{|l|}{ Apr. } \\
\hline $\begin{array}{l}\text { T. tabaci } \\
\text { A. obscurus } \\
\text { F. tritici } \\
\text { F. tenutcornis }\end{array}$ & $\begin{array}{l}\text { T. tabact } \\
\text { A. obscurus } \\
\text { F. tritici }\end{array}$ & $\begin{array}{l}\text { T. tabaci } \\
\text { A. obscurus } \\
\text { F. triticia } \\
\text { F. tenutcornis } \\
\text { A. rufus } \\
\text { Anaphothripini } \\
\text { Chirothripini }{ }^{a}\end{array}$ & & & L. denticornis \\
\hline
\end{tabular}

a 1982-83 only.

b 1983-84 only.

pots containing the foliage and soil and thrips were returned to the same fields from which they were removed and set into holes so that the top of the soil in the pots was even with the soil surface of the field. Each pot per row was randomly assigned a number from 1 to 12 , and this number determined the week that it was to be returned to the laboratory and examined. A set of samples, three for each field, was returned every other week beginning 16 November 1982 and ending 19 April 1983. The same procedures were followed during the winter of 1983-84 except that $50 \%$ of the pots per row received 25 larvae rather than adult $T$. tabaci, and samples were examined at 3-week intervals from 13 December 1983 to 27 March 1984. The pots were returned to the laboratory and stored at $3-4^{\circ} \mathrm{C}$ until they could be examined (within 48 $h$ of retrieval). Individual pots were rernoved from the cooler and taken to the laboratory: where the Nytex covering was carefully removed. Individual wheat shoots or alfalfa stems were ca:efully severed at the base and placed on a white surface. Individual shoots or stems were examined as they were taken apart, and both living and dead thrips were counted. The soil and plant root; were also examined. The top $2-3 \mathrm{~cm}$ of soil was carefully removed and placed on a white surface and examined microscopically for thrips. The remaining soil was placed into a saturated $\mathrm{NaCl}$ solution and gently agitated. After a 10 -min period to allow the thrips to float, the solution was poured through Nytex screening and the thrips were counted and identified. Live T. tabaci adults collected from pots were placed as a group (five thrips) on onion plants 


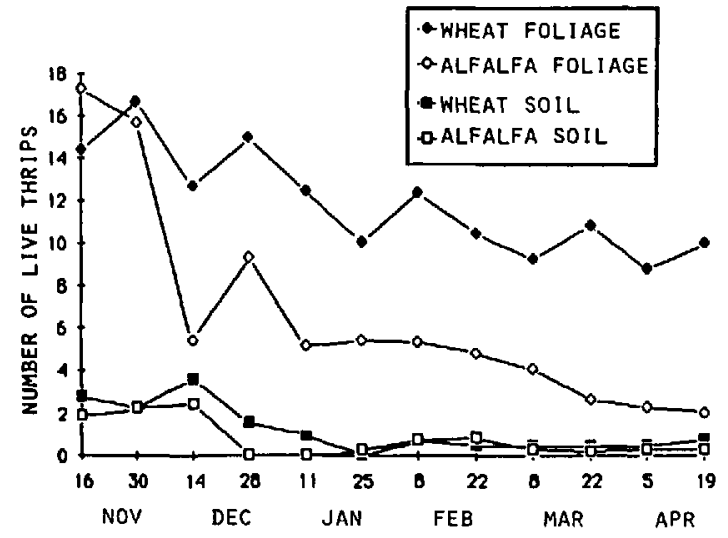

Fig. 1. Mean number (from nine sample units) of $T$. tabact adults recovered from wheat and alfalfa after an initial inoculation of $25 T$. tabaci adults per sample unit, 1982-83, Ontario County, N.Y.

contained within clear plastic cylinders with $\mathrm{Ny}$ tex lids. The onion plants were placed in a growth chamber at $27^{\circ} \mathrm{C}, 16: 8(\mathrm{~L}: \mathrm{D})$ photoperiod, and were examined 3 weeks later for T. tabaci larvae and adults. This was done so that we might determine if the females that overwintered could produce viable offspring.

Suitability of Hosts for T. tabaci. In 1984, winter wheat (Triticum vulgare Vill.), alfalfa (Medicago sativa L.), oat (Avena sativa L.), barley (Hordeum vulgare L.), Kentucky bluegrass (Poa pratensis $\mathrm{L}$.), timothy (Phleum pratense $\mathrm{L}$.), and smooth brome (Bromus inermis Leyss) were tested to ascertain if $T$. tabaci could oviposit, and whether any eggs would hatch and larvae develop on these plants. Timothy, smooth brome, and Kentucky bluegrass were chosen because they were present in significant proportions in the ditch areas. Barley is used as a winter cover crop, but it is also planted in the spring between the rows of onions to reduce soil erosion of muck soils and, thus, may serve as an initial breeding site or nutritional source for $T$. tabaci until the onions become suitable for colonization.

The seeds of these plants were planted at commercial densities in pots (13 cm diam) and were grown in the greenhouse at $20-27^{\circ} \mathrm{C}, 16: 8$ photoperiod. After growing for 6 weeks in the greenhouse, six pots of each plant species were selected and taken to a growth chamber set at $27^{\circ} \mathrm{C}, 16: 8$ photoperiod. This procedure was replicated four times in 1984. A clear plastic cylinder was placed over the plants, five adult female $T$. tabaci were added, and a Nytex lid was placed on the top of the cylinder. After 5 days, the stems and shoots from three pots of each plant species were cut at the base and the plant material was placed into a beaker with $50 \%$ ethanol. When the chlorophyll had dissolved, the stems and shoots were examined microscopically for thrips eggs. After another 7 days, the remaining three pots per species were

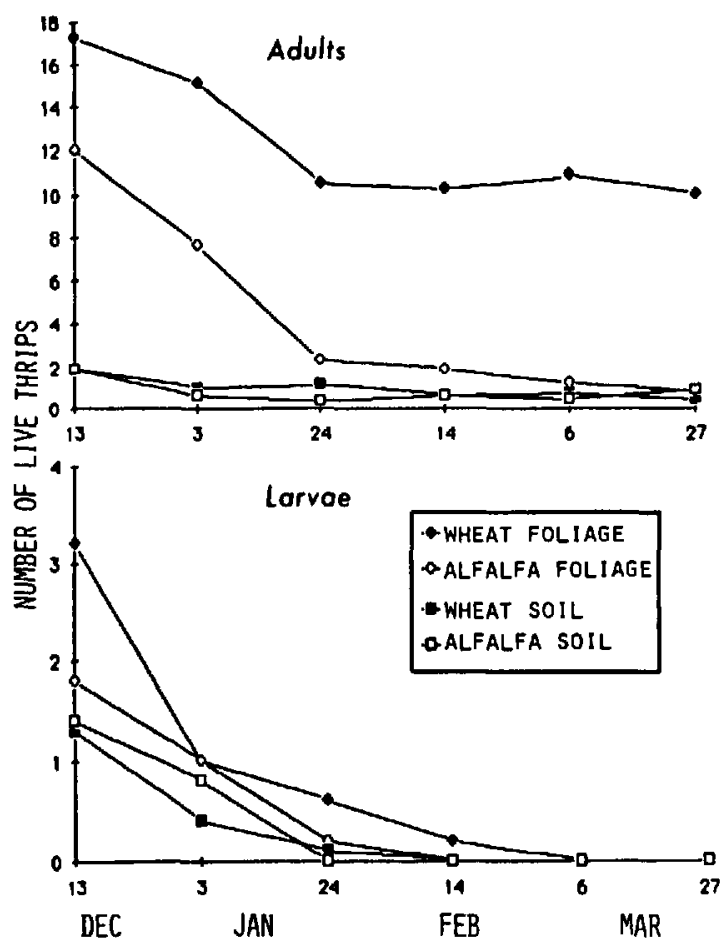

Fig. 2. Mean number (from nine sample units) of T. tabaci adults and larvae recovered from wheat and alfalfa after an initial inoculation of $25 T$. tabaci per sample unit during 1983-84, Ontario County, N.Y.

examined for larvae. The shoots and stems were carefully cut at the base and placed into $70 \%$ ethanol. The plant material was removed after 5-10 min, the solution strained through a Nytex screen, and the larvae counted.

\section{Results and Discussion}

Survey of Overwintering Thrips. Six species of adult thrips were collected during the winter of 1982-83: T. tabaci, Anaphothrips obscurus (Müller), Chirothrips manicatus Haliday, Frankliniella tritici (Fitch), Frankliniella tenuicornis (Uzel), and Aptinothrips rufus (Gmelin), as well as larvae from the tribes Thripini, Anaphothripini, and Chirothripini (Table 1). With the inclusion of barley in 1983-84, Limothrips denticornis (Haliday) adults were also collected. The mean number of thrips per sample was low throughout both winters, and this is consistent with the findings of Shirck (1951) and Boyce \& Miller (1953) of <1 thrip per sample during the coldest months. With so few thrips collected, the limited number of samples, and the problems of standardization of plant material collected per sample unit between the crops, it is inappropriate to draw conclusions about thrips abundance on each host. However, in both winters, ca. one $T$. tabaci adult per sample was collected from winter wheat, whereas alfalfa yielded 
Table 2. Number of larvae and adults produced per overwintering $T$. tabaci adult recovered from wheat or alfalfa and subsequently placed on onions

\begin{tabular}{|c|c|c|c|c|}
\hline \multirow{3}{*}{$\begin{array}{l}\text { Date of } \\
\text { recovery }\end{array}$} & \multicolumn{4}{|c|}{$\bar{x} \pm \mathrm{SE}$} \\
\hline & \multicolumn{2}{|c|}{ Wheat } & \multicolumn{2}{|c|}{ Alfalfa } \\
\hline & Larvae & Adults & Larvae & Adults \\
\hline $\begin{array}{l}\text { Nov. } 1982 \\
\text { Dec. } 1982 \\
\text { Jan. } 1983 \\
\text { Feb. } 1983 \\
\text { Mar. } 1983 \\
\text { Apr. } 1983\end{array}$ & $\begin{array}{r}7.3 \pm 2.5 \\
7.4 \pm 3.0 \\
11.8 \pm 6.2 \\
7.1 \pm 2.2 \\
12.3 \pm 5.2 \\
22.1 \pm 6.0\end{array}$ & $\begin{array}{l}2.0 \pm 0.8 \\
1.2 \pm 0.5 \\
2.2 \pm 1.3 \\
1.0 \pm 0.4 \\
1.7 \pm 1.1 \\
3.2 \pm 1.1\end{array}$ & $\begin{aligned} 8.7 & \pm 3.5 \\
10.5 & \pm 2.8 \\
8.1 & \pm 1.7 \\
7.0 & \pm 1.3 \\
10.1 & \pm 4.6 \\
17.2 & \pm 8.3\end{aligned}$ & $\begin{array}{l}1.4 \pm 0.7 \\
1.5 \pm 0.5 \\
1.0 \pm 0.4 \\
0.8 \pm 0.2 \\
1.0 \pm 0.4 \\
2.4 \pm 1.1\end{array}$ \\
\hline $\begin{array}{l}\text { Dec. } 1983^{a} \\
\text { Jan. } 1984 \\
\text { Feb. } 1984^{a} \\
\text { Mar. } 1984\end{array}$ & $\begin{array}{r}10.5 \pm 4.0 \\
6.5 \pm 2.5 \\
5.1 \pm 1.0 \\
13.2 \pm 3.0\end{array}$ & $\begin{array}{l}0.7 \pm 0.1 \\
1.1 \pm 0.4 \\
0.5 \pm 0.2 \\
1.1 \pm 0.6\end{array}$ & $\begin{array}{r}10.3 \pm 1.4 \\
5.6 \pm 2.6 \\
8.5 \pm 2.9 \\
12.2 \pm 3.0\end{array}$ & $\begin{array}{l}0.9 \pm 0.5 \\
0.6 \pm 0.5 \\
0.9 \pm 0.5 \\
1.0 \pm 0.4\end{array}$ \\
\hline
\end{tabular}

a One sample per month. All other months contained two samples per month.

$<0.5 T$. tabact per sample and weedy vegetation from road ditches $<0.2 T$. tabaci per sample. Oats and cabbage fields averaged $<0.1$ and $3 T$. tabaci per sample during the first few months of sampling, respectively, but no living $T$. tabaci were found in the plant material that we sampled in the spring. $T$. tabaci adults were also present within barley samples, but at $<0.4$ adults per sample. If $T$. tabaci adults overwintered in stubble of oats or barley, or both, they would have to disperse in the early spring to find new nutritive resources. Larvae of the Thripini (Thrips, Frankliniella) were collected in very low numbers, <0.1 larva per sample, and apparently did not survive the winter within the plant material that we examined. However, thrips larvae from the Anaphothripini (Anaphothrips, Aptinothrips) do successfully overwinter within weedy vegetation and alfalfa. Larvae of the Chirothripini (Limothrips, Chirothrips) would not be expected to overwinter (Lewis \& Navas 1962), so that the appearance in April of Chirothrips larvae may be an indication of the start of a new generation. Concurrent with the appearance of Chirothrips larvae in April 1983, $F$. tritici adults were collected from wheat, alfalfa, and weedy vegetation. Stannard (1968) has suggested that $F$. tritici migrates into northern latitudes in the spring and does not overwinter in Illinois. It is also possible that $T$. tabaci adults arrive with $F$. tritici and other wind-borne insects in upstate New York during spring. However, a thorough examination of the specimens of $T$. $t a$ - baci collected during spring leads us to conclude that they belong to the overwintering generation. All the specimens were dark brown, which is in agreement with the observations of Mound (1967) in England and Sakimura (1937) in Japan that overwintering $T$. tabaci are darker than the yellowish-brown adults collected in the late spring and summer.

$T$. tabaci Overwintering on Wheat and Alfalfa. The mean number of adults recovered from the leaf sheaths of the Nytex-covered potted wheat shoots in both years fell to ca. $45 \%$ of the original number by the termination of the experiment (Fig. 1 and 2). The number of dead thrips within wheat shoots in 1982-83 was ca. $1 \%$ in November and increased to ca. $5 \%$ during the final collections. Thrips populations on or in the soil were much lower than in the foliage. During the first half of both seasons, ca. another $5 \%$ of the original total was found alive on top or within the first $2-3 \mathrm{~cm}$ of soil within the pots. This number dropped to ca. $1 \%$ by the end of the season. Totals of $17 \mathrm{dead}$ adult thrips out of the original 2,700 in 1982-83 and 10 out of 1,350 in 1983-84 were found within this area during the entire season of sarnpling. Only 10 living and 2 dead thrips were founcl in the third area (i.e., soil and plant roots) during 1982-83. During 1983-84, a total of 10 dead adults out of the original 1,350 was collected in or on the soil and 6 living and 5 dead adults were collected in the soil-plant root area. Only ca. $4-5 \%$ of the 1,350 original larvae was found alive during December and January in the wheat shoots and the 2- to 3-cm soil area, and all larvae disappeared completely by February. Shirck (1951) and Boyce \& Miller (1953) also reported the lack of $T$. tabaci adults in the soil, and Gerdes (1982) did not find T. tabaci in soil beneath prairie plants in Illinois ard even suggested that soil may not be an ideal shelter for thrips in general. Koppa (1969) found T. tabaci overwintering in Finland within the shoots of wheat but in very low numbers.

Fewer thrips were recovered from alfalfa plants in each year, and only 8-10\% were recovered from foliage by March and April. The top 2-3 cm of soil yielded only ca. $1 \%$ in March and A.pril. Shirck (1951) and Boyce \& Miller (1953) reported that $T$. tabaci adults overwinter principally in the crowns of alfalfa plants and did not recover them from the soil. Alfalfa plants, unless the leaves are matted together or a number of plants are lodged by snow and rain, do not appear to offer thrips much pro-

Table 3. Mean numbers of eggs laid and larvae present per $T$. tabaci adult 5 and 12 days, respectively, after infestation on the crops in $13-\mathrm{cm}$ pots

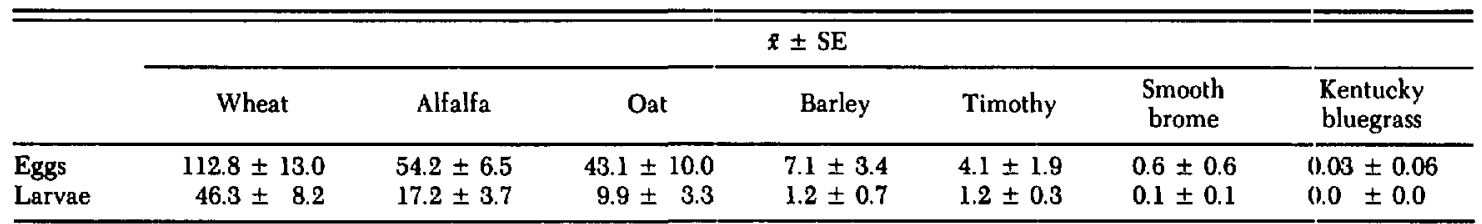


tection from the winter weather. This may account for the differences in the recovery of living $T$. tabaci from wheat and alfalfa. The trends for both years offer similar results and the mean low temperatures for $1982-83$ (January, $\bar{x}=-7.5^{\circ} \mathrm{C}$ ) and 1983-84 (December and March, $\bar{x}=-7.8^{\circ} \mathrm{C}$ ) are quite similar, but the initial low temperatures in December 1983 may account for the faster reduction of thrips numbers in 1983-84 within alfalfa.

The results obtained by placing the females collected from the previous experiment on onion plants are shown in Table 2 . Surviving adults were able to reproduce without a reproductive diapause, and there were no obvious differences in the means of larvae or adults obtained from the five females per onion plant between crops and years. Since the reproductive state of these adults was unknown, we are cautious about making any inferences regarding the potential fecundity of $T$. tabaci from these data.

Suitability of Hosts for $\boldsymbol{T}$. tabaci. Wheat, alfalfa, and oats appear to provide adequate oviposition substrates and to meet the nutritional needs of the developing larvae (Table 3). In comparison, barley and timothy incur less oviposition, and smooth broome and Kentucky bluegrass do not appear to meet the requirements for ovipositing $T$. tabaci.

Results from these experiments establish that $T$. tabaci adults can overwinter in upstate New York on winter wheat, alfalfa, and weedy vegetation. Apparently, after the emergence of winter wheat shoots in September and October, $T$. tabaci females enter the fields and overwinter there. $T$. $t a-$ baci are already present in alfalfa or weedy vegetation, or both, or may move into ditches from cabbage fields. The larvae of $T$. tabaci did not survive in the two winters that we collected samples, but Webster (1901) reported that it overwinters as larvae in Ohio. Winter wheat appears to be a more than adequate host and, thus, could provide an early season habitat for thrips (Shelton \& North 1986) and a subsequent source for their movement to adjacent vegetable crops during the ripening and senescence of the wheat (North \& Shelton 1986).

\section{Acknowledgment}

We thank W. T. Wilsey for his generous assistance under sometimes adverse conditions.

\section{References Cited}

Boyce, K. E. \& L. A. Miller. 1953. Overwintering habitats of the onion thrips, Thrips tabaci Lind. (Thysanoptera: Thripidae), in southwestern Ontario. Rep. Entomol. Soc. Ont. 84: 82-86.

Gerdes, C. F. 1982. Distribution of adult overwintering Thysanoptera in an Illinois prairie. J. Kans. Entomol. Soc. 55: 418-422.

Koppa, P. 1969. Studies on the hibernation of certain species of thrips living on cereal plants. Ann. Agric. Fenn. 8: 1-8.

Lewis, T. \& E. Navas. 1962 . Thysanoptera populations overwintering in hedge bottoms, grass litter, and bark. Ann. Appl. Biol. 50: 299-311.

Mound, L. A. 1967. The British species of the genus Thrips Thysanoptera. Entomol. Gaz. 18: 13-22.

North, R. C. \& A. M. Shelton. 1986. Ecology of Thysanoptera within cabbage fields. Environ. Entomol. 15: 520-526.

Sakimura, K. 1937. The life and seasonal histories of Thrips tabaci Lind. in the vicinity of Tokyo, Japan. Oyo Dobuts.-Zasshi 9: 1-24.

Shelton, A. M. \& R. C. North. 1986. Species composition and phenology of Thysanoptera within field crops adjacent to cabbage fields. Environ. Entomol. 15: 513-519.

Shirck, F. H. 1951. Hibernation of onion thrips in southern Idaho. J. Econ. Entomol. 44: 1020-1021.

Stannard, L. J. 1968. The thrips or Thysanoptera of Illinois. Ill. Nat. Hist. Surv. Bull. 29(4): 1-552.

Vance, T. C. 1974. Larvae of the Sericothripini (Thysanoptera: Thripidae), with reference to other larvae of the Terebrantia of Illinois. Ill. Nat. Hist. Surv. Bull. 31(5): 144-207.

Webster, F. M. 1901. The onion thrips. J. Columbus Hortic. Soc. 16: 73-80.

Received for publication 8 April 1985; accepted 7 March 1986. 